\title{
PERAN PENGAWASAN KONSUMEN DALAM TRANSAKSI \\ BISNIS ONLINE
}

Sri Anafarhanah

UIN Antasari Banjarmasin

\begin{abstract}
The facilities provided by e-commerce, to its customers do not escape the risks that will be borne by different parties, which can be in the form of technical and nontechnical. Problems in online transactions that often occur that occur in transactions and non-conformities of goods with specifications. In addition, the accessibility of traded goods is also a big mode of all online, intentionally or unintentionally. To eliminate it, the consumer must be smart through the transaction, the seller / trader, and the product to be bought. This is done as a form of consumer supervision for online business transactions. So that consumers are not always disadvantaged, the government has issued Law No. 8 of 1999 concerning consumer repentance. In addition to the law, consumers are also protected by the Indonesian Consumers Foundation (YLKI). YLKI is a nongovernmental and non-profit organization that aims to increase consumer awareness about the rights and responsibilities responsible for themselves and their environment. Whereas from the supervision of the consumer as a transaction agent, it can implement supervision, monitoring carried out in conjunction with the implementation of activities and feedback monitoring.
\end{abstract}

Keywords: Consumer Supervision, Online Business

\section{Pendahuluan}

Jual-beli melalui jaringan internet sekarang bukan hanya sekedar lifestyle, melainkan menjadi sebuah pelengkap kebutuhan kehidupan sehari-hari, dimana perkembangan teknologi yang semakin pesat dan produk yang dijual bukan hanya software atau aplikasi, tetapi juga menjual produk yang diperlukan sehari-hari dan sulit ditemukan dipasar konvensional dan tradisional. Sebagian lembaga dan organisasi menggunakan aplikasi internet untuk pemasaran produk, terkait dengan pemasaran secara online, sektor transportasi juga memakai internet pada penjualan tiket guna mempermudah para pembeli dalam mendapatkan tiket jauh sebelum hari keberangkatan.

Seiring dengan perkembangan teknologi, ada sisi positif dan negatif yang ditawarkan. Kemudahan yang ditawarkan oleh transaksi online membuat para pengguna merasa sangat diuntungkan, akan tetapi disisi lain para pengguna juga perlu berhati-hati dengan tindakan 
penipuan yang disebabkan oleh penjual karena antara pembeli dan penjual tidak pernah bertemu sebelumnya. Transaksi ini terjadi atas dasar kebutuhan dan kepercayaan, bagi penjual yang bisa menjaga amanah maka transaksi bisa berjalan dengan lancar, akan tetapi bagi penjual yang mengambil keutungan sepihak tentunya akan sangat merugikan pembeli. Karena itulah maka para pembeli hendaknya berhati-hati ketika bertansaksi dipasar online ini.

\section{Pembahasan}

\section{Pengawasan Dalam Manajemen}

Ada banyak sebutan bagi fungsi pengawasan (controlling), antara lain evaluating, appraising, atau correcting. Sebutan controlling lebih banyak digunakan karena lebih mengandung konotasi yang mencakup penetapan standar, pengukuran kegiatan, dan pengambilan tindakan korektif. ${ }^{1}$

Pengawasan (controlling) dapat didefinisikan sebagai proses untuk menjamin bahwa tujuan-tujuan organisasi dan manajemen dapat tercapai. Ini berkenaan dengan cara-cara membuat kegiatan-kegiatan sesuai yang direncanakan. Pengertian ini menunjukkan adanya hubungan yang sangat erat antara perencanaan dan pengawasan. Pengawasan membantu penilaian apakah perencanaan, pengorganisasian, penyusunan personalia, dan pengarahan telah dilaksanakan secara efektif.
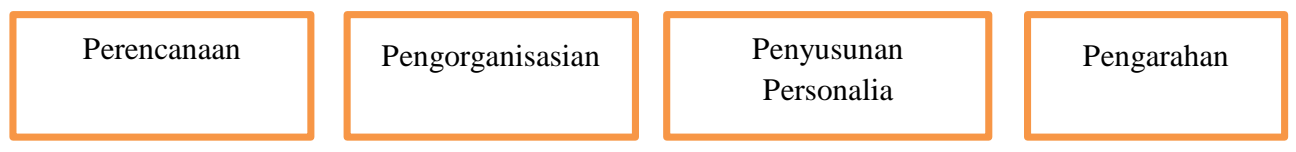

Pengawasan
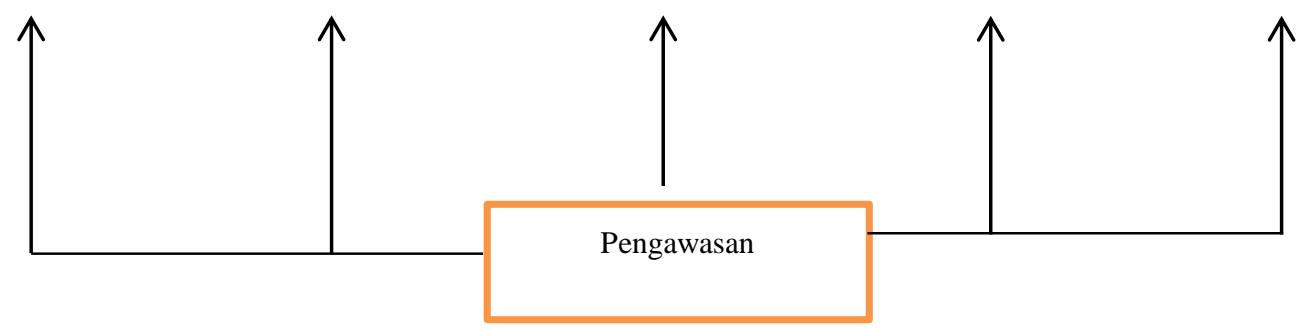

Gambar 2.1 Hubungan Pengawasan dengan fungsi-fungsi manajemen lainnya Definisi pengawasan yang dikemukakan oleh Robert J. Mockler berikut ini telah memperjelas unsur-unsur esensial proses pengawasan:

\footnotetext{
${ }^{1}$ T. Hani Handoko, Manajemen, (Yogyakarta: BPFE, 2015), Edisi kedua, hlm. 357
} 
Pengawasan manajemen adalah suatu usaha sistematik untuk menetapkan standar pelaksanaan dengan tujuan-tujuan perencanaan, merancang sistem informasi umpan balik, membandingkan kegiatan nyata dengan standar yang telah ditetapkan sebelumnya, menantukan dan mengukur penyimpangan-penyimpangan, serta mengambil tindakan koreksi yang diperlukan untuk menjamin bahwa semua sumber daya perusahaan dipergunakan dengan cara yang paling efektif dan efisien dalam pencapaian tujuan-tujuan perusahaan. ${ }^{2}$

\section{Tipe-Tipe Pengawasan}

Ada tiga tipe dasar pengawasan, yaitu (1) pengawasan pendahuluan, (2) pengawasan concurrent, dan (3) pengawasan umpan balik, seperti yang ditunjukkan gambar dibawah ini.

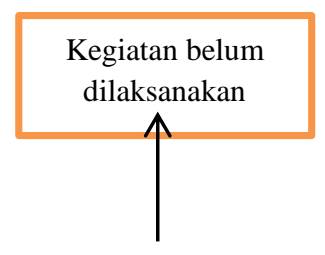

Feedforward

Control

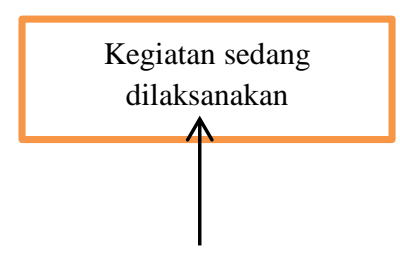

Concurent

Control

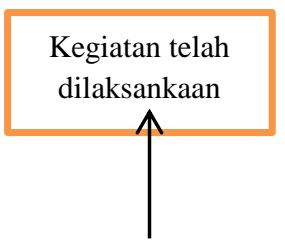

Feedback

Control

Gambar 2.2 Tipe-tipe Pengawasan

a. Pengawasan pendahuluan (feedforward control) sering disebut juga sebagai steering controls, dirancang untuk mengantisipasi masalah-masalah atau penyimpanganpenyimpangan dari standar atau tujuan dan memungkinkan koreksi dibuat sebelum suatu tahap kegiatan tertentu diselesaikan. Jadi, pendekatan pengawasan ini lebih aktif dan agresif, dengan mendeteksi masalah-masalah dan mengambil tindakan yang diperlukan sebelum suatu masalah terjadi. Pengawasan ini akan efektif hanya bila manajer mampu mendapatkan informasi akurat dan tepat pada waktunya tentang perubahan-perubahan dalam lingkungan atau tentang perkembangan terhadap tujuan yang diinginkan.

b. Pengawasan yang dilakukan bersamaan dengan pelaksanaan kegiatan (concurrent control). Pengawasan ini, sering disebut pengawasan "Ya-Tidak", screening control atau "berhenti-terus"; dilakukan selama suatu kegiatan berlangsung. Tipe pengawasan ini

\footnotetext{
${ }^{2}$ Ibid. 358
} 
merupakan proses dimana aspek tertentu dari suatu prosedur harus disetujui dulu, atau syarat tertentu harus dipenuhi dulu sebelum kegiatan-kegiatan bisa dilanjutkan, atau menjadi semacam peralatan "double-check" yang lebih menjamin ketepatan pelaksanaan suatu kegiatan.

c. Pengawasan umpan balik (feedback control). Pengawasan umpan balik, juga dikenal sebagai past-action controls, mengukur hasil-hasil dari suatu kegiatan yang telah diselesaikan. Sebab-sebab penyimpangan dari suatu rencana atau standar ditentukan, dan penemuan-penemuan diterapkan untuk kegiatan-kegiatan serupa di masa yang akan datang. Pengawasan ini bersifat historis, pengukuran dilakukan setelah keinginan terjadi. ${ }^{3}$

\section{Tahap-Tahap dalam Proses Pengawasan}

Proses pengawasan biasanya terdiri paling sedikit lima tahap (langkah), yakni:

a. Penetapan standar pelaksanaan (perencanaan)

Standar mengandung arti sebagai suatu satuan pengukuran yang dapat digunakan sebagai "patokan" untuk penilaian hasil-hasil. Tujuan, sasaran, kuota, dan target pelaksanaan dapat digunakan sebagai standar. Bentuk standar yang lebih khusus antara lain target penjualan, anggaran, bagian pasar (market-share), margin keuntungan, keselamatan kerja, dan sasaran produksi.

Tiga bentuk standar yang umum adalah:

1) Standar-standar fisik, mungkin meliputi kuantitas barang atau jasa, jumlah langganan, atau kualitas produk.

2) Standar-standar moneter, yang ditunjukkan dalam rupiah dan mencakup biaya tenaga kerja, biaya penjualan, laba kotor, pendapatan penjualan, dan sejenisnya.

3) Standar-standar waktu, meliputi kecepatan produksi atau batas waktu suatu pekerjaan harus diselesaikan. ${ }^{4}$

b. Penentuan pengukuran pelaksanaan kegiatan

Beberapa pertanyaan yang penting berikut ini dapat digunakan dalam penentuan pengukuran pelaksanaan kegiatan yakni: berapa kali (how often) pelaksanaan seharusnya diukur setiap jam, harian, mingguan, bulanan? Dalam bentuk apa (what form) pengukuran akan dilakukan- laporan tertulis, inspeksi visual, melalui telepon? Siapa (who) yang akan

\footnotetext{
${ }^{3}$ Ibid, hlm. 360

${ }^{4}$ Ibid, hlm. 361
} 
terlibat- manajer, staf departemen? Pengukuran ini sebaiknya mudah dilaksanakan dan tidak mahal, serta dapat diterangkan kepada karyawan.

c. Pengukuran pelaksanaan kegiatan nyata

Setelah frekuensi pengukuran dan sistem monitoring ditentukan, pengukuran pelaksanaan dilakukan sebagai proses yang berulang-ulang dan terus-menerus. Ada berbagai cara untuk melakukan pengukuran pelaksanaan, yaitu 1) pengamatan (observasi), 2) laporanlaporan (baik lisan dan tertulis), 3) metoda-metoda otomatis, dan 4) inspeksi, pengujian (tes), atau dengan pengambilan sampel. Banyak perusahaan sekarang mempergunakan pemeriksa intern (internal auditor) sebagai pelaksana pengukuran.

d. Pembandingan pelaksanaan kegiatan dengan standar dan penganalisisan penyimpanganpenyimpangan

Tahap kritis dari proses pengawasan adalah pembandingan pelaksanaan nyata dengan pelaksanaan yang direncanakan atau standar yang telah ditetapkan. Walaupun tahap ini paling mudah dilakukan, tetapi kompleksitas dapat terjadi pada saat menginterpretasikan adanya penyimpangan (deviasi). Penyimpangan-penyimpangan harus dianalisis untuk menentukan mengapa standar tidak dapat dicapai.

e. Pengambilan tindakan koreksi bila perlu

Bila hasil analisis menunjukkan perlunya tindakan koreksi, tindakan ini harus diambil. Tindakan koreksi dapat diambil dalam berbagai bentuk. Standar mungkin diubah, pelaksanaan diperbaiki, atau keduanya dilakukan bersamaan. Tindakan koreksi tersebut dapat berupa:

1) Mengubah standar mula-mula (barangkali terlalu tinggi atau terlalu rendah)

2) Mengubah pengukuran pelaksanaan (inspeksi terlalu sering frekuensinya atau kurang atau bahkan mengganti sistem pengukuran itu sendiri).

3) Mengubah cara dalam menganalisa, dan menginterpretasikan penyimpanganpenyimpangan. ${ }^{5}$

\section{Pentingnya Pengawasan}

\footnotetext{
${ }^{5}$ Ibid. hlm. 363
} 
Ada berbagai faktor yang membuat pengawasan semakin diperlukan oleh setiap organisasi. Faktor-faktor itu adalah:

a. Perubahan lingkungan organisasi. Seperti munculnya inovasi produk dan pesaing baru, ditemukannya bahan baku baru, adanya peraturan pemerintah baru, dan sebagainya. Melalui fungsi pengawasan manajer mendeteksi perubahan-perubahan yang berpengaruh pada barang dan jasa organisasi, sehingga mampu menghadapi tantangan atau memanfaatkan kesempatan yang diciptakan perubahan-perubahan yang terjadi.

b. Peningkatan kompleksitas organisasi. Semakin besar organisasi semakin memerlukan pengawasan yang lebih formal dan hati-hati. Berbagai jenis produk harus diawasi untuk menjamin bahwa kualitas dan profitabilitas tetap terjaga, penjualan eceran pada para penyalur perlu dianalisis dan dicatat secara tepat; bermacam-macam pasar organisasi, luar dan dalam negeri, perlu selalu dimonitor. Disamping itu organisasi sekarang lebih bercorak desentralisasi, dengan banyak agen-agen atau cabang-cabang penjualan dan kantor-kantor pemasaran, pabrik-pabrik yang terpisah secara geografis, atau fasilitasfasilitas penelitian yang tersebar luas. Semuanya memerlukan pelaksanaan fungsi pengawasan dengan lebih efisien dan efektif.

c. Kesalahan-kesalahan. Bila para bawahan tidak pernah membuat kesalahan, manajer dapat secara sederhana melakukan fungsi pengawasan. Tetapi kebanyakan anggota organisasi sering membuat kesalahan-kesalahan. Memesan barang atau komponen yang salah, membuat penentuan harga yang terlalu rendah, masalah-masalah diagnosa secara tidak tepat. Sistem pengawasan memungkinkan manajer mendeteksi kesalahan-kesalahan tersebut sebelum menjadi kritis.

d. Kebutuhan manajer untuk mendelegasikan wewenang. Bila manajer mendelegasikan wewenang kepada bawahannya tanggung jawab atasan itu sendiri tidak berkurang. Satusatunya cara manajer dapat menentukan apakah bawahan telah melakukan tugas-tugas yang telah dilimpahkan kepadanya adalah dengan mengimplementasikan sistem pengawasan. $^{6}$

\section{Transaksi Bisnis Online}

\footnotetext{
${ }^{6}$ Ibid, hlm. 364
} 


\section{Konsep Bisnis}

Bisnis (businesses) adalah suatu organisasi yang menghasilkan barang dan/atau jasa yang kemudian dijual dengan tujuan untuk memperoleh keuntungan (profit). Baik perusahaan yang berskala kecil (seperti rumah makan dan toko kelontongan) maupun perusahaan yang berskala besar (seperti PT) merupakan suatu bisnis. ${ }^{7}$

Bisnis merupakan kegiatan beresiko memberikan kerugian baik dari segi material atau nonmaterial. Namun bila berhasil maka akan memberikan keuntungan dan kesejahteraan bagi pemiliknya. Agar terhindar dari resiko bisnis maka bisnis harus dijalankan dengan tepat dengan perencanaan yang matang dan pelaksanaan yang serius dan mantap. Bisnis terdiri atas beberapa komponen penting yang saling mendukung dan melengkapi. Bila salah satu komponen gagal maka akan mengganggu komponen lain. Komponen-komponen bisnis itu antara lain adalah: ${ }^{8}$

a. Manajemen, yaitu bagian yang merencanakan, mengelola, dan menjalankan bisnis. Komponen ini bisa disebut sebagai backend yaitu komponen yang berada di belakang layar.

b. Kekuatan brand atau image, yaitu karisma, kekuatan emosional yang dimiliki oleh perusahaan dan merupakan pandangan/perasaan masyarakat terhadap perusahaan atau produk.

c. Produk atau Layanan, komponen yang dijual atau ditawarkan kepada pasar. Komponen ini bisa disebut sebagai front end karena komponen ini berada didepan. Komponen inilah yang berhadapan dengan masyarakat.

d. Partner, yaitu pihak yang ikut membantu dalam menjalankan bisnis.

e. Pelanggan, yaitu pihak yang akan menerima tawaran atau membeli produk dan layanan yang ditawarkan.

\section{Penggunaan Teknologi Internet dalam Bisnis}

Internet sudah mulai banyak dipraktekkan sejak tahun 1996. Internet banyak memberikan keuntungan bagi organisasi maupun perusahaan yang menggunakannya, dengan browser yang menyederhanakan pengelolaan informasi internal dan meningkatkan komunikasi

\footnotetext{
${ }^{7}$ Sunardi dan Anita Primastiwi, Pengantar Bisnis: Konsep, Strategi, \& Kasus, (Yogyakarta: CAPS, 2015), hlm.1

${ }^{8}$ http://pengertianmanagement.blogspot.co.id/2012/11/management-bisnis.html. Diakses tanggal 27 Juli 2016.
} 
eksternal. ${ }^{9}$ Gedung putih pada bulan Juli tahun 1997, mendeklarasikan terjadinya sebuah revolusi industri baru yang akan memberi dampak pada perekonomian global. ${ }^{10}$ Menurut Toffler, Era globalisasi ditandai dengan berkembangnya teknologi elektronik yang hampir mempengaruhi seluruh seluk beluk kehidupan masyarakat. ${ }^{11}$

Teknologi yang berkembang di akhir abad ke-20 mentransformasi masyarakat dan bisnis dan menciptakan potensi problem etis baru. Yang paling mencolok di antara perkembangan ini adalah revolusi dalam bioteknologi dan apa yang sering disebut teknologi informasi, bukan hanya perkembangan komputer yang sangat pesat, namun juga perkembangan internet, komunikasi nirkabel, digitalisasi, dan banyak teknologi lainnya yang memungkinkan semua orang untuk menangkap, memanipulasi, dan menggerakkan informasi dengan cara baru yang kreatif. ${ }^{12}$

Tren yang paling signifikan pada saat ini adalah E-Commerce atau electric commercial. E-Commerce berkembang sangat cepat dan menjadi sangat penting. Internet pada dasarnya menyediakan sarana untuk menjalankan bisnis, sehingga para pengusaha yang memahaminya dapat mengkreasikan dan memperluas bisnisnya secara lebih cepat dan mudah daripada sebelumnya. ${ }^{13}$

\section{Electric Commercial (E-Commerce)}

Pergeseran cara bertransaksi mulai dengan cara barter hingga transaksi jual-beli melalui internet atau lebih popular disebut sebagai e-commerce merupakan salah satu solusi untuk mengurangi kerugian pada awal membuka usaha. Hampir 90\% pengusaha non e-commerce mengalami kerugian diawal. Keunggulan e-commerce dari jual-beli traditional yaitu dapat mengurangi biaya operasional yang harus di keluarkan oleh jual beli traditional, seperti kertas, toko yang luas untuk memajang barang, dan juga memperpendek jarak perusahaan dengan konsumen sehingga sungguh efisien dari sudut waktu. ${ }^{14}$

\footnotetext{
${ }^{9}$ Adi Nugroho, E-commerce Memahami Perdagangan Modern Didunia Maya, (Bandung: Informatika, 2006), hlm. 5.

${ }^{10}$ Haris Faulidi Asnawi, Transaksi Bisnis E-commerce Perspektif Islam, (Yogyakarta: MSI UII, 2004), hal.13.

${ }^{11}$ Alvin Toffler, The Third Wave, (Toronto.: Bantam Books.,t.t.), hal. 155.

12 Sunardi dan Anita Primastiwi, Pengantar Bisnis: Konsep, Strategi, \& Kasus, (Yogyakarta: CAPS, 2015), hlm. 33

13 Ibid, hlm. 45

${ }^{14}$ Haris Faulidi Asnawi, Transaksi Bisnis E-commerce Perspektif Islam, (Yogyakarta: MSI UII, 2004),
} hlm. 14 . 


\section{Pengertian E-Commerce}

E-Commerce menurut Undang-Undang Republik Indonesia Tahun 2008 No 11 tentang Informasi dan Transaksi Elektronik Pasal 1 Ayat 2 menyatakan bahwa "Transaksi Elektronik adalah perbuatan hukum yang dilakukan dengan menggunakan Komputer, jaringan komputer, dan/atau media elektronik lainnya". Kata e-commerce merupakan singkatan dari electric commercial (perdagangan elektronik), yaitu sebuah sistem dagang yang menggunakan jaringan elektronik. Menurut Sutan Remi Sjahdeni e-commerce adalah suatu kegiatan bisnis yang menyangkut konsumen (consumer), manufaktur (manufactures), servis providers dan perdagangan perantara (intermediateries), dengan menggunakan jaringan komputer (computer network) yaitu Internet. $^{15}$

Pada aplikasinya e-commerce memerlukan beberapa faktor penunjang, faktor penunjang tersebut adalah:

a. Adanya kedua belah pihak yang bertransaksi Marchant (perusahaan online), dan konsumen.

b. Browsing, pencarian informasi mengenai Toko Online di Internet.

c. Pemesanan melalui Internet (web,e-mail, dll).

d. Pembayaran secara elektronik.

e. Pengiriman barang.

f. Setelah pengiriman

\section{Macam-Macam Bentuk E-Commerce}

E-Commerce dibagi menjadi tiga macam bentuk transaksi, yaitu Business to Business (B2B), Business to Consumer (B2C) dan Consumer to Consumer (C2C).

a). E-Commerce dari Bisnis ke Bisnis (B2B).

Bentuk pertama dari e-commerce, business to business (B2B) sekitar $80 \%$ transaksinya masih menggunakan sistem berbayar pada pertukaran data elektronik (EDI-electronic data interchange). Pemesanan dikirimkan ke manajer toko online yang

\section{1), hlm. 15}

${ }^{15}$ Sutan Remi Sjahdeni, E-commerce dalam Perspektif Hukum, Jurnal Keadilan, Jilid 1, No 3 (September, 
kemudian akan dikirim ulang dengan basis data pemesanan melalui EDI, atau email ke penyedia (supplier) agar dapat mengetahui ketersediaan barang. ${ }^{16}$

EDI dapat mengotomatisasikan pertukaran dokumen antar pihak yang bertransaksi, seperti penagihan bayaran, surat jalan, dan pemesanan pembelian. Perusahaan atau organisasi yang mengunakan EDI sebagai sarana transaksi dapat terlibat langsung pada produksi dengan pemesanan secara otomatis, pemilik memiliki akses online tertentu kepada Departemen Produksi Perusahaan yang jadwal pengirimannya secara otomatis mengirimkan produk yang dipesan oleh pihak perusahaan tanpa intervensi agen pembelian perusahaannya. ${ }^{17}$

Trading partners antar perusahaan yang sudah saling mengenal cukup lama maka pertukaran B2B hanya dilandasi asas kebutuhan dan kepercayan. Pertukaran data dapat dilangsungkan berulang-ulang dan berkala sesuai dengan format data yang sudah disepakati dengan menggunakan standar yang sama. Beberapa contoh produk yang biasa ditransaksikan melalui B2B seperti menjual gas alam cair, bahan bakar, bahan kimia, dan plastik.

Dampak dari jual beli e-commerce B2B cukup signifikan, selain menghemat biaya sampai 95\% juga memperluas jangkauan pemasaran, seperti dituliskan CEO Indo.Com Eka N Ginting. Ada dua aliran fundamental mengenai dampak internet bagi B2B. Pertama, pemikiran McKindey \& Company, salah satu perusahaan strategic \& management consulting terkemuka, ia menyatakan bahwa internet itu dapat meningkatkan efesiensi untuk interaksi yang terjadi di dunia bebas. Seperti halnya biaya interaksi, meeting, mencetak dan menyebarkan brosur/katalog mengenai produk/jasa, laporan keuangan, dll. Demikian juga yang berhubungan dengan komunikasi dari satu pihak di dalam perusahaan dengan pihak lain, baik di dalam maupun di luar perusahaan, bisa sedemikian rupa dipangkas dari beberapa persen hingga 95\% sehingga dampaknya bisa menjurus pada kualitatif.

b) E-Commerce dari Bisnis ke Konsumen (B2C).

\footnotetext{
${ }^{16}$ Onno W. Purbo, Aang Arif Wahyudi, Mengenal E-commerce, (Jakarta: Elex Media Komputindo, 2001), hlm 2.

${ }^{17}$ Kenneth, C. laudon dan jane P. laudon, Management information System, Alih bahasa Criswan Sungkono dan Machmudin Eka P , edisi 10 buku 2, (Jakarta: Salemba Empat, 2008), hal. 70
} 
Business to Consumer (B2C) merupakan salah satu model dari transaksi secara langsung (direct transaction), pada B2C Organisasi secara langsung menjual produk kepada konsumen, dilakukan secara umum, dan terbuka untuk semua. Informasi disebarkan secara umum, dengan servis yang standar sehingga mekanismenya dapat digunakan secara umum. Seperti website Amazon.com, Barnesandnoble.com yang menjual buku, software, dan musik kepada konsumen perorangan. Lebih jelasnya, B2C merupakan akhir dari perputaran B2B "End-point of a business-to-business value chain". 18

Menurut Anastasia yang dikutip oleh Dendi B2C mempunyai karakteristik adalah sebagai berikut: ${ }^{19}$

1) Terbuka untuk umum, dimana informasi disebarkan secara umum.

2) Service yang dilakukan bersifat umum, sehingga mekanismenya dapat digunakan oleh banyak orang.

3) Service yang diberikan berdasarkan konsumen. Konsumen berinisiatif sedangkan produsen harus memberikan respon.

Standar pemesanan B2C biasanya dapat melalui e-mail, web/situs, chat/video confrance, hingga melalui media telekomunikasi seperti telpon selular. Transaksi $e$ commerce sebenarnya sudah sering digunakan oleh masyarakat kita Indonesia, hanya saja tidak semua orang menyadari bahwa ia sudah melakuan transaksi e-commerce. Sebagai contohnya, transaksi e-commerce melalui telpon selular dapat dilihat ketika pengisian pulsa atau ketika pengecekan pulsa melalui telpon selular, pada halaman pertama kita akan disuguhi dengan beberapa fitur, untuk fitur pengecekan pulsa tidak mendapatkan beban biaya, pada fitur lain seperti NSP (nada sambung pendek) dikenakan beban biaya untuk mendownload NSP tersebut. Setiap pembelian NSP secara otomatis provider telpon selular mengurangi pulsa sebagai biaya pembelian NSP dengan jangka waktu yang telah ditentukan oleh pihak provider, jika jangka waktu akan habis pihak provider akan menawarkan kembali untuk meneruskan NSP atau memberhentikannya.

\footnotetext{
${ }^{18} \mathrm{~J}$ Botha dkk, Managing e-Commerce, (Republic of South Africa: Paarl Print, 2004), hlm. 98.

${ }^{19}$ Anastasia Diana, Mengenal E-Bisnis (Yogyakarta:Andi 2001), hal 17, Dendi Riswandi, ecommerce dalam perbankan syari'ah,.. hlm 30
} 
c) E-Commerce dari Konsumen ke Konsumen (C2C).

Bentuk ketiga e-commerce adalah consumer to consumer $(\mathrm{C} 2 \mathrm{C})$, yaitu transaksi yang dilakukan antar konsumen untuk memenuhi kebutuhan. ${ }^{20}$ Pihak konsumen secara langsung menjual ke konsumen yang lain, Contohnya seperti Ebay.com, Clasified2000.com, OLX.com (sebelumnya tokobagus.com), dan Kaskus.com. Contoh dari beberapa situs yang telah disebutkan di atas memberikan fasilitas kepada orangorang (konsumen) untuk melelangkan barang kepada konsumen yang lain dan menjualnya kepada penawar tertinggi. ${ }^{21}$ Proses pemesanan pada $\mathrm{C} 2 \mathrm{C}$ tidak jauh berbeda dengan pemesanan B2C, masih menggunakan web/situs, melalui chat, alat komunikasi Non-PC. Proses pembayaran juga dapat dilakukan dengan cara COD (Cash On Delivery), yaitu pihak penjual langsung bertemu dengan pihak pembeli, setelah kesepakatan dua belah pihak.

Penjelasan mengenai macam-macam bentuk transaksi e-commerce ini bertujuan untuk membedakan sistem dalam transaksinya, antara bentuk transaksi B2B dan B2C tentu berbeda yangmana B2B mempunyai standard pemesanan yang diketahui oleh pihak-pihak yang bertransaksi. Pada transaksi C2C sistem pemesanan yang digunakan tidak jauh berbeda dengan sistem pemesanan yang ada pada $\mathrm{B} 2 \mathrm{C}$, hanya pada $\mathrm{C} 2 \mathrm{C}$ ada pihak ketiga yang menjadi perantara antar pihak yang bertransaksi dan memberikan sarana transaksi seperti website sebagai wadah untuk melakukan transaksi.

\section{Mekanisme Transaksi Jual-Beli E-Commerce}

Pembahasan mengenai Mekanisme dalam Transaksi E-Commerce berhubungan dengan prapembelian, pemesanan, pembayaran, pengiriman, dan kelanjutan setelah pengiriman. Pada pembayarannya e-commerce menggunakan pembayaran elektronik, dalam pengiriman objek $e$ commerce terbagi pada perangkat lunak (software) dan perangkat keras (hardware), objek yang berbentuk software akan dikirimkan secara langsung melalui jaringan internet dan yang berbentuk hardware seperti Monitor, CPU, dan alat elektronik lainnya akan dikirimkan melalui jasa

\footnotetext{
${ }^{20}$ Haris Faulidi Asnawi, Transaksi Bisnis E-commerce Perspektif Islam, (Yogyakarta: MSI UII, 2004), hlm.18-23.

${ }^{21}$ J Botha dkk, Managing e-Commerce, (Republic of South Africa: Paarl Print, 2004), hlm. 63
} 
pengiriman. Keamanan dan keutuhan barang akan dijamin oleh pihak penjual hingga barang sampai dipihak pembeli.

\section{Peran Pengawasan Konsumen Dalam Transaksi Bisnis Online (Electric Commercial)}

\section{Dampak E-Commerce terhadap Produsen dan Konsumen}

Dampak dari adanya internet sebagai hasil revolusi teknologi informasi bagi konsumen di satu sisi telah mengubah perilaku konsumen menjadi semakin kritis dan selektif dalam menentukan produk yang akan dipilihnya. Konsumen memiliki akses yang lebih besar pada bermacam-macam produk. Begitu pula bagi produsen, kemajuan ini memberi dampak positif dalam memudahkan pemasaran produk sehingga dapat memotong jalur distribusi yang akan berakibat pada penghematan biaya dan waktu, serta memudahkan produsen dalam menghimpun database pelanggan secara elektronik, di samping kemudahan-kemudahan lainnya.

Transaksi e-commerce berbeda dengan transaksi perniagaan konvensional yang bersifat langsung (face to face), sebab transaksi e-commerce berlangsung di dunia maya (cyberspace), tidak mempertemukan secara langsung pembeli dengan penjual serta barang yang ditawarkan (faceless nature). Karena kedua belah pihak secara fisik tidak bertemu maka kemungkinan lahirnya bentuk-bentuk kecurangan atau kekeliruan menjadi perhatian utama yang perlu penanganan lebih besar.

Dampak negatif dari e-commerce itu sendiri cenderung merugikan konsumen. Diantaranya dalam hal yang berkaitan dengan produk yang dipesan tidak sesuai dengan produk yang ditawarkan, kesalahan dalam pembayaran, ketidaktepatan waktu menyerahkan barang atau pengiriman barang dan hal-hal lain yang tidak sesuai dengan kesepakatan sebelumnya. Disamping itu, bagi produsen, banyaknya jumlah orang yang dapat mengakses internet mengakibatkan produsen kesulitan untuk mendeteksi apakah pembeli yang hendak memesan produknya adalah pembeli yang sesungguhnya atau bukan.

\section{Peran Pemerintah terhadap Perlindungan Konsumen}

Budi Agus Riswandi mengungkapkan bahwa "Masalah perlindungan konsumen dalam $e$ commerce merupakan aspek yang penting untuk diperhatikan, karena beberapa karakteristik khas e-commerce akan menempatkan pihak konsumen pada posisi yang lemah atau dirugikan seperti: 
a. Perusahaan di internet (the internet merchant) tidak memiliki alamat secara fisik di suatu negara tertentu, sehingga hal ini akan meyulitkan konsumen untuk mengembalikan produk yang tidak sesuai dengan pesanan.

b. Konsumen sulit memperoleh jaminan untuk mendapatkan local follow up service or repair.

c. Produk yang dibeli konsumen ada kemungkinan tidak sesuai atau tidak kompatible dengan persyaratan lokal (local requairments). ${ }^{22}$

Kondisi di atas jelas merugikan baik bagi konsumen ataupun bagi produsen terlebih konsumen yang relatif memiliki posisi tawar (bargaining position) yang lebih rendah dibandingkan produsen/pelaku usaha. Lemahnya posisi konsumen seringkali menjadi obyek aktivitas untuk memperoleh keuntungan sebesar-besarnya dari produsen, sehingga keseimbangan yang diharapkan melalui hubungan jual beli tidak tercapai.

Perlindungan hukum terhadap konsumen di Indonesia atas pemanfaatan barang atau jasa dari produsen/pelaku usaha diatur dalam Undang-Undang Perlindungan Konsumen No 8 Tahun 1999 (UUPK). Undang-undang ini telah disahkan pada tanggal 20 April 1999, sekalipun baru berlaku setahun kemudian. Namun, setelah satu semester diberlakukannya UUPK, masih banyak masyarakat konsumen yang belum pernah mendengar tentang keberadaan UUPK. ${ }^{23}$ Selain itu, ketidaktahuan konsumen e-commerce akan hak-haknya menjadi salah satu penghambat terlaksananya perlindungan hukum bagi dirinya.

Perlindungan hukum terhadap konsumen dalam melakukan transaksi e-commerce mutlak diperlukan. Perlindungan konsumen itu sendiri menurut Pasal 1 ayat (1) UUPK menyebutkan "Perlindungan konsumen adalah segala upaya yang menjamin adanya kepastian hukum untuk memberi perlindungan kepada konsumen”.

Selain Undang-Undang, konsumen juga dilindungi oleh Yayasan Lembaga Konsumen Indonesia (YLKI). YLKI merupakan organisasi non-pemerintah dan nirlaba yang bertujuan untuk meningkatkan kesadaran kritis konsumen tentang hak dan tanggung jawabnya sehingga dapat melindungi dirinya sendiri dan lingkungannya. ${ }^{24}$

Kenyamanan yang ditawarkan oleh e-commerce pada pelanggannya tidak luput dari risiko yang akan ditanggung oleh kedua belah pihak, risiko tersebut bisa berupa teknis dan

\footnotetext{
${ }^{22}$ Budi Agus Riswandi. Hukum dan Internet di Indonesia. (Yogyakarta: UII Press, 2003), hlm. 62

${ }^{23}$ Lihat Dewi Lestari, Konsumen E-Commerce dan Permasalahannya, 31 Juli 2004, tersedia pada www.lkht-fhui.com/e-commerce

${ }^{24}$ http://id.m.wikipedia.org/wiki/yayasan_lembaga_konsumen_Indonesia. Diakses tanggal 27 Juli 2016
} 
non teknis, salah satu kesalahan non teknis seperti aliran listrik yang tiba-tiba padam, sehingga kehilangan kesempatan bisnis karena gangguan pelayanan. Pada kesalahan teknis contohnya kasus yang menimpa pada Amazon.com dan Steples.com yang telah mencantumkan harga yang salah atas produk DVD, mainan, dan koper yang mengakibatkan puluhan pesanan telah didiskon secara drastis namun pelaku usaha hanya mengirimkan beberapa bagian pesanan yang diterimanya. Kesalahan yang terjadi cukup membuat kesal sejumlah pembeli, sehingga konsumen mengadukan hal tersebut kepada federal trade commission (FTC) dan better business bureau (BBB). ${ }^{25}$

\section{Menjadi Konsumen yang Cerdas}

Agar resiko kerugian konsumen bisa diminimalisir, maka perlu adanya peranan atau kerjasama dari pihak konsumen untuk berhati-hati dalam bertransaksi bisnis online. Ada beberapa hal yang bisa dilakukan konsumen agar terhindar dari kerugian, antara lain :

i. Melakukan pengawasan pendahuluan (feedforward control)

Sering disebut juga sebagai steering controls, dirancang untuk mengantisipasi masalah-masalah atau penyimpangan-penyimpangan dari standar atau tujuan dan memungkinkan koreksi dibuat sebelum suatu tahap kegiatan tertentu diselesaikan. Jadi, pendekatan pengawasan ini lebih aktif dan agresif, dengan mendeteksi masalah-masalah dan mengambil tindakan yang diperlukan sebelum suatu masalah terjadi. Dalam mekanisme transaksi online konsumen akan menjalani tahap pra-pembelian, dimana saat itu konsumen bisa menentukan toko online mana yang akan dipilih untuk membeli barang-barang yang dibutuhkannya seperti, makanan, pakaian, alat elektronik, tiket travel, dan lain-lain.

Cara yang lebih mudah untuk mencari alamat webstore dapat dengan mencarinya melalui Direktori Toko Online yaitu sebuah bookmark website toko online, tahap selanjutnya disusun sesuai dengan katagori jenis bisnis, berikutnya konsumen hanya perlu memilih katagori bisnis setelah itu akan ditampilkan keterangan mengenai toko online dengan lengkap.

\footnotetext{
${ }^{25}$ Abdul Halim Barakatullah dan Syahrida, Sengketa Transaksi E-commerce International Pengertian, Sebab Kemunculan dan Metode Penyelesaian yang Efektif, (Banjarmasin: FH UNLAM Press, 2010), hlm. 6.
} 
Dengan mencari daftar toko online tersebut maka kita akan terhindar dengan situssitus yang tidak bertanggung jawab.

ii. Pengawasan yang dilakukan bersamaan dengan pelaksanaan kegiatan (concurrent control).

Pengawasan ini, sering disebut pengawasan "Ya-Tidak", screening control atau "berhenti-terus"; dilakukan selama suatu kegiatan berlangsung. Tipe pengawasan ini merupakan proses dimana aspek tertentu dari suatu prosedur harus disetujui dulu, atau syarat tertentu harus dipenuhi dulu sebelum kegiatan-kegiatan bisa dilanjutkan, atau menjadi semacam peralatan "double-check" yang lebih menjamin ketepatan pelaksanaan suatu kegiatan.

Dalam transaksi bisnis online setelah menemukan toko online yang sesuai, selanjutnya adalah melakukan pemesanan dan pembayaran. Biasanya pembayaran dilakukan setelah pihak marchant memberikan konfirmasi, konfirmasi tersebut bisa berupa e-mail, fax, atau sms, isi dari konfirmasi tersebut berupa keterangan bahwa waktu untuk pengiriman biaya dapat dilakukan maksimal 2 x 24 jam. Pembayaran yang telat dari waktu yang ditentukan dianggap batal oleh pihak marchant. Seandainya konsumen ingin membelinya lagi maka ia harus memilih kembali dari awal, proses pembelian kembali diulangi seperti proses awal pemesanan. Sampai tahapan proses ini, konsumen masih bisa membatalkan pembeliannya karena biasanya barang tidak akan dikirim oleh penjual sampai ada bukti transfer dari konsumen. Akan tetapi masalah bisa muncul pada saat konsumen sudah melakukan pembayaran, tetapi barang yang dipesan tidak sampai. Biasanya kesalahan ini terjadi karena kesalahan penjual atau ekspedisi yang dipakai. Maka dalam hal ini peran konsumen sangat penting untuk aktif mencari kebenarannya. Jika barang yang dimaksud memang tidak pernah dikirim ke alamat konsumen, maka bisa jadi transaksi itu merupakan tindakan penipuan.

iii. Pengawasan umpan balik (feedback control).

Pengawasan umpan balik, juga dikenal sebagai past-action controls, mengukur hasil-hasil dari suatu kegiatan yang telah diselesaikan. Sebab-sebab penyimpangan dari suatu rencana atau standar ditentukan, dan penemuan-penemuan diterapkan untuk kegiatan-kegiatan serupa di masa yang akan datang. Pengawasan ini bersifat historis, pengukuran dilakukan setelah keinginan terjadi. Dalam transaksi bisnis online pernah terjadi kesalahan yakni tidak sesuainya barang yang dipesan dengan barang yang sampai 
kepada konsumen. Bagi sebagian penjual, biasanya memberikan tempo untuk penukaran barang yang tidak sesuai. Akan tetapi ada sebagian penjual yang tidak menerima kesalahan itu. Sehingga pada saat seperti ini konsumen akan dirugikan.

Dari ketiga tipe/ bentuk pengawasan tersebut di atas, sangat membantu konsumen agar terhindar dari kerugian baik yang tidak disengaja atau disengaja oleh penjual. Ketersediaan informasi yang benar dan akurat mengenai konsumen dan perusahaan dalam e-commerce merupakan suatu persyaratan mutlak.

\section{Simpulan}

Bisnis online atau Electric commercial yaitu sebuah sistem dagang yang menggunakan jaringan elektronik. Kemajuan teknologi telah membawa masyakat untuk menjadikan transaksi bisnis online sebagai kegiatan kebutuhan masyarakat saat ini karena pada kenyataannya barang yang tersedia dianggap mudah, murah dan lengkap meski resiko kerugian juga sarat terjadi dalam transaksi ini. Sebagai konsumen yang cerdas, masyarakat akan lebih hati-hati dalam menentukan pilihan transaksinya. 


\section{DAFTAR PUSTAKA}

Riswansi, Budi Agus. 2003. Hukum dan Internet di Indonesia. Yogyakarta: UII Press.

Asnawi, Haris Faulidi. 2004. Transaksi Bisnis E-commerce Perspektif Islam. Yogyakarta: MSI UII.

Botha, J dkk. 2004. Managing e-Commerce. Republic of South Africa: Paarl Print.

Barakatullah, Abdul Halim dan Syahrida. 2010. Sengketa Transaksi E-commerce International Pengertian, Sebab Kemunculan dan Metode Penyelesaian yang Efektif. Banjarmasin: FH UNLAM Press.

Diana, Anastasia. 2001. Mengenal E-Bisnis. Yogyakarta: Andi

Handoko, T. Hani. 2015. Manajemen. Edisi kedua. Yogyakarta: BPFE.

Kenneth, C. laudon dan jane P. laudon. 2008. Management Information System. Alih bahasa Criswan Sungkono dan Machmudin Eka P, edisi 10 buku 2. Jakarta: Salemba Empat.

Nugroho, Adi. 2006. E-commerce Memahami Perdagangan Modern Didunia Maya. Bandung: Informatika.

Purbo, Onno W dan Aang Arif Wahyudi. 2001. Mengenal E-commerce. Jakarta: Elex Media Komputindo.

Sunardi dan Anita Primastiwi. 2015. Pengantar Bisnis: Konsep, Strategi, \& Kasus. Yogyakarta: CAPS.

Sjahdeni, Sutan Remi. 2001. E-commerce dalam Perspektif Hukum, Jurnal Keadilan, Jilid 1, No 3.

Toffler, Alvin. t.t. The Third Wave. Toronto: Bantam Books.

http://pengertianmanagement.blogspot.co.id/2012/11/management-bisnis.html. Diakses tanggal 27 Juli 2016.

http://id.m.wikipedia.org/wiki/yayasan_lembaga_konsumen_Indonesia. Diakses tanggal 27 Juli 2016. 